\title{
A Study on Schmidt's The Novel: A Biography
}

\author{
Zheng FU \\ Department of Foreign Languages, Henan University of Animal Husbandry and \\ Economy, Zhengzhou, China
}

12456745@163.com

Keywords: Schmidt, Literature, The Novel: A biography, Literary criticism, Development.

\begin{abstract}
Michael Schmidt's The Novel: A Biography(2014) is an ambitious,erudite study exploring the 700-year history of the novel in English.Tracing the intensification of interest in the story of the novel in English as a privileged unit of world literature, Schmidt rethinks its complexity that unfolds like a richly varied landscape one would like to explore in depth. Exquisitely written, meticulously conceived, and deeply learned, The Novel:A Biography draws our attention to tensions within the logics of substitution, representation, and identification upon which novelists both male and female often stake their claims.
\end{abstract}

\section{Introduction}

Michael Schmidt's The Novel: A Biography(2014) is an ambitious, erudite study exploring the 700-year history of the novel in English. Tracing the intensification of interest in the story of the novel in English as a privileged unit of world literature, Schmidt rethinks its complexity that unfolds like a richly varied landscape one would like to explore in depth. Exquisitely written, meticulously conceived, and deeply learned, The Novel: A Biography draws our attention to tensions within the logics of substitution, representation, and identification upon which novelists both male and female often stake their claims. Drawing on their biographies, Schmidt further invites us into the creative dialogues between authors and between books and suggests how these dialogues have shaped the development of the novel in English. Speaking about the novel, Schmidt maintains that "a novelist makes formal calculations" that may not present themselves in this deliberate form, but are "choices whose rightness, more than the detail of the story, engages a reader".

\section{The Progressive Development of Schmidt's Literary Career}

The first section of the book focuses on a range of subjects that a novelist would write about and each subject forms a chapter in which a group of novelists are closely examined with reference to their affinities between each other. Schmidt argues that "a novel is a kind of rabbit hole" (6), for it "led Gorky's Nastiah into all-absorbing emotion, the Victorian schoolboy into adventure, and a young Mexican into an imaginary, heroic Europe" (6). There are 8 chapters in this part and Schmidt begins in earnest with Sir John Mandeville, the first invented English narrator, highlighting "the English prose tradition from which the novel emerges" (21). Chapter 2 turns to the history of the novel in which Schmidt discovers relevant English and European antecedents. In his opinion, "what would develop into a core readership for the novel was shaping in the late fourteenth and the fifteenth centuries. In the sixteenth it developed and grew" (25). Here Schmidt sees the novel as 
a form rooted in medieval soil growing with protestant individualism, education, technology, and capitalism. What follows is an exploration of the three springs of the novel in English namely Sir Philip Sidney, Samuel Richardson and Thomas Lodgeforeseeing Charles Dickens who "has the same rich abundance of matter, the sense of words and events pressing for admission" (53). John Bunyan stands alone as the subject of Chapter 4 in which Schmidt elaborates what makes Bunyan's predictable story, passage by passage derivative of the Bible, so compelling and durable, offering in his The Pilgrim's Progress a reality of allegorical figuration and good humor. Chapter 5, in a similar vein, examines two novelists Aphra Behn and Zora Neale Hurston who both touch on "issues of imperialism, colonialism, class and race, central to modern academic discourse" (65). Unique as it is, this chapter singles out how the novel in English enters America, for Behn anticipates both Alex Hayley's Roots: The Saga of An American Family (1976) and Zora Neale Hurston's Their Eyes Were Watching God (1937), for they root their language "not only in speech but in specific speech" (70). Alongside this geographical traveling of the novel is his transnational discussion of Daniel Defoe, Truman Capote and J. M. Coetzee in Chapter 6 titled "Impersonation" which continues to argue about the stereotypes imprinted on the Anglophone reader. It is a comparative study of Robinson Crusoe's man Friday and Behn's black-skinned European Oroonoko, offering a contrasted view of the other embodied in both Friday and Oroonoke. 'Defoe perceived a set of physical and qualitative differences that set Friday apart" while "Behn wanted to include Oroonoke among 'us"” (74). When he embodies and formalizes a division, Defoe actually animates his stories by way of characterization setting a far better example for his heirs of three kinds in the twentieth century: "those who try for his sort of verisimilitude and thematic relevance in journalistic terms, those who revisit his themes from modern points of view, and those who build on the moral force of his single-mindedness with a refining artistry" (85). They are Thomas Keneally, Truman Capote and J. M. Coetzee. The remaining two chapters of this section address respectively "proportion" and "sex and sensibility" bringing about an array of novelists who have acted upon each other. In Chapter 7, for example, Jonathan Swift is "a brilliant savage who understands, though he cannot control, the spiritual, political, and literary jungle in which he exists" (93), but in the eye of Schmidt Swift is largely indebted to the French writer François Rabelais who "found his way into English in the mid-seventeenth century and was fortunate to have been translated by the inventive, spirited, if not always accurate Scot Sir Thomas Urquhart" (97) who "[is] irresistible to Alasdair Gray, most of all for his language, his crazy bagatelles"(109). Urquhart's Rabelais, though steeped in medievalallegory, represents a decisive break with its constraints. Whereas, in Chapter 8, Diderot is approached from a comparative perspective, exhibiting how Samuel Richardson, a moral hubris has sprung from his wide reading of Diderot and Behn. Richardson did not invent the epistolary novel, maintains Schmidt, but his influence on Jane Austen is remarkable, for she liked "his focus on individuals, the inherence of the informing historical and moral contexts" (119). If there is a lacuna in Schmidt's biographical outline of the novel, it is the way he groups the authors, which is not quite easy for the reader to grasp if there is no mention of how they interrelate each other across languages and cultures. The slightly disconcerting result isthat many significant facts get no mention at all, and they are noticedonly fleetingly. 


\section{The Readers' Interesting in the Eminent Literary Genre}

This life of the eminent literary genre is especially interesting to novel readers who are compelled to appreciate its biographer's craft. Schmidt covers so huge a body of novelists who have acted upon each other throughout ages. The book also treats individually a novelist's personal life from his or her toilet training to the sexual and marital affairs which have impaired his or her education and career. The following chapters form a vast landscape of the novel in English as Schmidt states clearly in his prologue, "the writers came together in configurations that seemed to [him] expressive: there was a dialogue between them or their works," for example, Salman Rushdie and Anita Desai "have more to say to Michael Ondaatje and Margaret Atwood, and to Peter Carey and David Malouf, than they do to R. K. Narayan and Mulk Raj Anand" (3). Here we are occasionally getting immersed in fascinating dialogues featured by geographical, ideological, cultural and sexual zoning. Many interesting things surface as we read on and find chapters 23 and 27, or 27 and 29, 37, 38 and 43 could be combined. Schmidt's argument of modern core lies in Chapters 30 through 36 in which "the succession and juxtaposition of modernists, their beneficiaries and detractors, in an academic account might have taken other forms" (3). While speaking about enchantment and disenchantment, Schmidt cites a group of authors and parallels them with Vladimir Nabokov who, like Beckett, "made the transition between language alive to the different semantic and expressive properties of each" (812). His unexpected comparison of Muriel Spark and Nabokov is illuminative, showcasing possible interrelatedness among writers like Ayn Rand, Radclyffe Hall, Ivy Compton-Burnett, Elizabeth Taylor, Muriel Spark, Nabokov, William Cass, John Barth, Thomas Pynchon, B. S. Johnson and Jonathan Franzen. In his discussion of Johnson, Schmidt emphasizes in particular his radicalism defined by "personal and political, not academic, experience" (835), believing that Johnson exploited and undermined the conventional novel form despite his occasional inheritance from the literary tradition as any of his fellow writers does, for he cut holes through pages so the reader could see forward. Johnson, Schmidt goes on, left unbound chapters to shuffle the text and give it the anachronic quality ofmemory (835). Also, he analyzes Pynchon's point of departure from Kafka's novel The Trial (848) and Franzen's main personal risk in his fiction to leave satire behind, highlighting their varying contributions to the novel (849-50). Of equal significance is Chapter 37 which offers a meticulously researched extension of genre studies bringing together various authors and works which will be appealing to a wide range of scholars interested in the study of genre and writing practices of the novel.

\section{The Value of Schmidt's The Novel: A Biography}

In tracing the various manifestations of the novel in English, Schmidt offers a brilliant life of it in which he identifies a significant nexus of national, international, and cosmopolitan interests that accompany the development of the novel. His detailed reading of the novel in English is particularly valuable in this respect. This major instance of the most recent scholarship centers on the novel and its influence on the human mind. As has been demonstrated in the last two chapters, the novel in English, having survived more than 700 years, is now going beyond its border exhibiting its global significances. A case in point is Chapter 44 titled "Truth in Fiction, the Metamorphosis of Journalism" which, starting from a study of E. L. 
Doctorow's novels, explores deftly how Doctorow "sets the scene with Camus, Sartre, Tolstoy" (1051).

Overall, then, Michael Schmidt's The Novel: A Biography enriches rather than merely adds detail to the novel's 700-year history of cultural and literary life. For this, he has skillfully mined and then deployed anecdotes and ideas from various writers of the novel in English in addition to quoting largely from their voluminous letters, diaries, journals, reviews and notebooks. Though not so much an intellectual biography as the biography of an intellectual such as Alfred Kazin: A Biography, The Novel: A Biography does recreate the essential intellectual, moral and political framework with which we can grasp the centrality of the novel throughout its development. Rather than exhaustinginterest in the novel, Schmidt has succeeded in offering a fresh re-introductionto one of the most powerful literary genres of what Schmidt refers to as "a liberalizing force and a revolutionary stimulus"(479). The value of Schmidt's work, after all, lies not in the conclusions he has arrived at, but in the process he has gone through to reach such conclusions. In addition, the timeline section appendixed at the end of the book is extremely informative and resourceful sorting out major authors of the novel in English and notions regarding each one's year of birth.

\section{Conclusion}

Fittingly in some ways, Schmidt concludes with a chapter on "Pariahs" reiterating not only the cultural and historical transformation of the novel but its far-reaching supernatural interventions across languages and cultures. For him, North American novelists who intend to throw offEurope never altogether manage it (1082). The same is true of Australian writers as well as Canadian ones. Having quibbled with the book's framework and a few passing remarks on it, however, I must end by reiterating my strong admiration for Schmidt's overall achievement. His The Novel: A Biography is the most thoroughgoing and insightful treatment of the genre to date, and a mandatory purchase for all literary scholars.

\section{References}

[1] Schmidt, Michael. The Novel: A Biography. Cambridge, MA: The Belknap P of Harvard UP, 2014.

[2] Schramm, Jan-Melissa. Atonement and Self-Sacrifice in Nineteenth-Century Narrative. Cambridge: Cambridge UP, 2012. 